\title{
Hubungan Sosialisasi Gender dalam Keluarga dengan Persepsi Gender Siswa SMK
}

\author{
Amalia Nur Ramadhani ${ }^{1}$, Nanang Martono $^{2}$, dan Tri Rini Widyastuti ${ }^{3}$ \\ ${ }^{2}$ Program Studi Sosiologi Universitas Jenderal Soedirman Purwokerto
}

\begin{tabular}{|c|c|}
\hline Informasi Artikel & ABSTRAK \\
\hline $\begin{array}{l}\text { Kata Kunci: } \\
\text { Gender; Sosialisasi; Persepsi; Keluarga }\end{array}$ & $\begin{array}{l}\text { Artikel ini menjelaskan hubungan sosialisasi gender dalam } \\
\text { keluarga dengan persepsi gender siswa SMK. Penelitian ini } \\
\text { dilakukan dengan menggunakan metode survei di salah } \\
\text { satu SMK di Purbalingga, Jawa Tengah. Populasi } \\
\text { penelitian ini adalah siswa SMK yang berjumlah } 498 \\
\text { siswa, dan sampel diambil dengan metode acak sederhana } \\
\text { sebesar 30\% dari total populasi. Hasil penelitian } \\
\text { menunjukkan nilai korelasi tau kendall kedua variabel } \\
\text { tersebut sebesar 0,14 dengan nilai signifikansi 0,07. Hal ini } \\
\text { berarti terdapat hubungan positif antara sosialisasi gender } \\
\text { dalam keluarga persepsi gender responden. Aktivitas yang } \\
\text { dilakukan responden bersama orang tua menjadi } \\
\text { kesempatan berlangsungnya sosialisasi gender dalam } \\
\text { keluarga. Hal tersebut menjadi salah satu sarana } \\
\text { pembentukan persepsi gender responden. Ketika orang tua } \\
\text { memperlakukan anak laki-laki dan perempuan secara } \\
\text { berbeda, maka hal tersebut dapat membentuk persepsi } \\
\text { bahwa keduanya adalah berbeda. Nilai korelasi antara } \\
\text { variabel sosialisasi gender dalam keluarga dengan persepsi } \\
\text { gender responden adalah sangat rendah, sehingga dapat } \\
\text { dikatakan bahwa sosialisasi gender dalam keluarga } \\
\text { bukanlah faktor dominan yang membentuk persepsi gender } \\
\text { responden. Ada faktor lain yang turut menentukan persepsi } \\
\text { ini, di antaranya: sosialisasi di sekolah, sosialisasi dengan } \\
\text { teman sebaya, lingkungan masyarakat berdasarkan budaya } \\
\text { termasuk media massa. }\end{array}$ \\
\hline \multirow{2}{*}{$\begin{array}{l}\text { Keywords: } \\
\text { Gender; Socialization; Perception; } \\
\text { Family }\end{array}$} & ABSTRACT \\
\hline & $\begin{array}{l}\text { This article describes the relationship between gender } \\
\text { socialization in the family and the gender perceptions } \\
\text { of vocational school students. This research was } \\
\text { conducted using a survey method at one of the } \\
\text { vocational schools in Purbalingga, Central Java. The } \\
\text { population of this research was vocational high } \\
\text { school students, amounting to } 498 \text { students, and the } \\
\text { sample was taken by simple random method of } 30 \% \text { of } \\
\text { the total population. The results showed that the tau } \\
\text { kendall correlation value of the two variables was } \\
0.14 \text { with a significance value of } 0.07 \text {. This means that }\end{array}$ \\
\hline
\end{tabular}


there is a positive relationship between gender socialization in the respondent's family of gender perceptions. Activities carried out by respondents with their parents provide an opportunity for gender socialization to take place in the family. This is one of the means to form respondents' gender perceptions. When parents treat boys and girls differently, it can form the perception that the two are different. The correlation value between the variable of gender socialization in the family and the respondent's gender perception is very low, so it can be said that gender socialization in the family is not the dominant factor that shapes the respondent's gender perception. There are other factors that determine this perception, including: socialization at school, socialization with peers, the community environment based on culture, including the mass media.

\section{Pendahuluan}

Isu gender bukanlah isu baru dalam diskusi ilmiah di banyak tempat, namun isu ini masih menjadi aktual dan menarik karena banyak masyarakat kurang memahami persamaan peran sosial lakilaki dan perempuan. Hal inilah yang memicu ketidakadilan gender dan mengakibatkan kesenjangan peran sosial laki-laki dan perempuan. Perbedaan gender ini disosialisasikan, diperkuat, bahkan dikonstruksi secara sosial atau kultural. Melalui serangkaian proses tersebut, gender kemudian dianggap bersifat kodrati yang tidak dapat diubah lagi. Oleh karena itu, penyimpangan terhadap peran gender akan dianggap hal negatif atau salah sebagai penentang sosial budaya gender (Rustin, 2017; Sumiarti \& Munfarida, 2015). Gender merupakan konsep yang membedakan peran laki-laki dan perempuan melalui proses sosialisasi, penguatan dan konstruksi sosial, kultural, dan keagamaan, bahkan melalui kekuasaan negara (Probosiwi, 2015). Misalnya, bahwa perempuan itu lemah lembut, cantik, dan emosional, sedangkan laki-laki dianggap sebagai orang yang kuat, perkasa, dan rasional.

Pemahaman individu mengenai gender dapat ditingkatkan melalui sosialisasi berbagai media dan agen sosialisasi tertentu. Sosialisasi merupakan proses interaksi sosial yang menyebabkan individu belajar berpikir, berperasaan, bertingkah laku, dan mengenal kebudayaan dari anggota masyarakat sehingga membuat individu berperan dalam masyarakat yang berhubungan dengan sistem sosial (Syarif, 2017; Miskahuddi, 2014). Menurut Mackie (Warmiyati, Wijayanti, \& Darmoyo, 2018, p. 412) sosialisasi gender merupakan penanaman nilai yang melibatkan proses belajar sehingga seorang individu akan menjadi feminin atau maskulin sesuai dengan harapan masyarakat. Sosialisasi gender diawali dengan sosialisasi primer dalam keluarga. Sosialisasi gender dalam keluarga menggambarkan bahwa 
konstruksi sosial seorang anak laki-laki dan perempuan berbeda. Anak laki-laki digambarkan sebagai individu yang kuat, agresif, berani, dan atribut lain yang menyimbolkan kelelakian berdasarkan konstruksi sosial. Gambaran karakter tersebut melekat pada sosok ayah sebagai kepala keluarga. Anak perempuan digambarkan sebagai sosok yang lemah lembut, penyayang, emosional, dan sebagainya. Karakter perempuan tersebut digambarkan pada sosok seorang ibu yang mengurus anak dan keluarga.

Perbedaan peran laki-laki dan perempuan dibentuk melalui nilai-nilai budaya yang melandasi perlakuan terhadap masing-masing individu. Proses ini diwariskan dari generasi ke generasi yang dimulai dari lingkungan keluarga. Masyarakat kemudian ikut menguatkan bagaimana seharusnya seorang laki-laki dan perempuan bersikap atau berbuat (Miskahuddi, 2014; Berliana, 2014). Proses sosialisasi peran gender dapat dilakukan melalui berbagai cara, mulai dari perbedaan pemilihan warna pakaian, aksesoris, permainan, perlakuan, dan sebagainya. Proses ini dilakukan untuk mendukung pembentukan karakter individu menjadi seorang laki-laki atau perempuan sesuai ketentuan sosial budaya masyarakat setempat.

Sosialisasi gender dalam keluarga akan membentuk persepsi individu mengenai gender yang kemudian dapat memengaruhi tindakan individu. Menurut William \& Best (Kusumo, Andriani, \& Charina, 2013) persepsi gender merupakan kepercayaan normatif tentang bagaimana seharusnya penampilan seseorang laki-laki atau perempuan, apa yang seharusnya dikerjakan laki-laki atau perempuan, dan bagaimana cara keduanya berinteraksi.
Menurut Rakhmat (Jayanti \& Arista, 2018) persepsi gender adalah pengamatan tentang laki-laki dan perempuan yang diperoleh dengan menyimpulkan informasi dan menafsirkan peran laki-laki dan perempuan.

Orang tua memiliki peranan penting dalam menentukan peran gender individu. Pembentukan peran gender ini dipengaruhi pemahaman orang tua mengenai nilai gender. Jika orang tua memperlakukan anak laki-laki dan perempuan secara berbeda, maka hal tersebut akan menumbuhkan kesadaran bahwa keduanya adalah berbeda. Orang tua pun kemudian memberikan hak, kewajiban, kesempatan, dan tanggung jawab berbeda. Ketika dewasa mereka pun akan menganggap bahwa perbedaan tersebut merupakan kodrat yang harus mereka terima (Ratri, 2019). Pemahaman tersebut memengaruhi pilihan anak terhadap keputusan dan tindakan yang akan dilakukannya.

Penelitian terkait isu gender dilakukan Warmiyati, dkk (2018) mengenai pemahaman gender pada siswa SMA di Jakarta. Hasil penelitian menyatakan bahwa konstruksi budaya yang disosialisasikan terus-menerus oleh agen-agen sosialisasi menghasilkan stereotype laki-laki harus terlihat gagah, kuat, dan rasional, sedangkan perempuan harus lemah lembut, penyabar, emosional, dan menyenangkan.

Penelitian yang dilakukan Rahayu \& Wigna (2010) mengenai persepsi gender di kalangan responden menghasilkan kesimpulan bahwa secara umum persepsi gender responden lebih banyak dipengaruhi lingkungan sekolah dan pergaulan dengan teman sebayanya. Akan tetapi terdapat perbedaan faktor yang 
memengaruhi persepsi gender antara lakilaki dan perempuan. Persepsi gender lakilaki lebih banyak dipengaruhi guru sekolah dan pergaulannya dengan temannya. Berdeda dengan responden perempuan lebih sering dipengaruhi peran ibu yang membentuk persepsi mengenai kedudukan laki-laki dan perempuan.

Penelitian ini dilakukan berbeda dari referensi penelitian terdahulu tersebut, yaitu lebih menjelaskan hubungan antara sosialisasi gender dalam keluarga dengan persepsi gender. Penelitian ini menjadi menarik karena hasil penanaman nilai-nilai gender mudah dilihat di kalangan siswa SMK. Hal ini dapat dilihat dari pemilihan jurusan di SMK yang mengandung "bias gender", sehingga di SMK dikenal sebutan "jurusan feminim dan "jurusan maskulin". Jurusan feminin adalah jurusan yang didominasi perempuan, yaitu: jurusan akuntansi dan keuangan lembaga, administrasi publik, serta bisnis daring dan pemasaran. "Jurusan maskulin" adalah jurusan yang didominasi laki-laki, yaitu: jurusan rekayasa perangkat lunak serta teknik komputer dan jaringan.

Penelitian ini dilakukan di salah satu SMK negeri di Purbalingga, Jawa Tengah. SMK tersebut memiliki jurusan akuntansi dan keuangan lembaga siswa perempuan sebesar 90,14\%; jurusan administrasi publik hampir seluruh siswa perempuan, yakni sebesar $95,80 \%$; jurusan bisnis daring dan pemasaran sebanyak 91,30\% siswa perempuan. Sebaliknya pada jurusan rekayasa perangkat lunak siswa laki-laki mendominasi, yakni sebesar 65,2\%; dan di jurusan teknik komputer dan jaringan siswa laki-laki sebesar 63,8\%. Perbedaan jumlah siswa perempuan dan laki-laki di setiap jurusan tersebut dapat menjadi indikasi bahwa siswa SMK memiliki persepsi yang berbeda antara peran laki-laki dan perempuan. Alasan tersebut menjadi landasan peneliti untuk menjadikan siswa SMK sebagai objek penelitian mengenai persepsi gender berdasarkan pengalaman mereka karena perbedaan perempuan dan laki-laki dalam jurusan tertentu dapat menjadi indikasi bahwa siswa SMK memiliki persepsi gender yang berbeda antara laki-laki dan perempuan.

Penelitian ini dilakukan berbeda dari referensi penelitian terdahulu tersebut, yaitu lebih menjelaskan hubungan antara sosialisasi gender dalam keluarga dengan persepsi gender. Penelitian ini menjadi menarik karena hasil penanaman nilai-nilai gender mudah dilihat di kalangan siswa SMK tersebut. Hal ini dapat dilihat dari pemilihan jurusan di SMK yang mengandung "bias gender", sehingga di SMK dikenal sebutan "jurusan feminim dan "jurusan maskulin”. Jurusan feminin adalah jurusan yang didominasi perempuan, yaitu: jurusan akuntansi dan keuangan lembaga, administrasi publik, serta bisnis daring dan pemasaran. "Jurusan maskulin" adalah jurusan yang didominasi laki-laki, yaitu: jurusan rekayasa perangkat lunak serta teknik komputer dan jaringan.

\section{Metode}

Penelitian ini menggunakan metode survei yaitu sebuah metode penelitian yang dilakukan dengan menyebarkan sejumlah pertanyaan kepada responden untuk menjawab permasalahan yang diteliti (Creswell \& Creswell, 2018). Objek penelitian ini adalah siswa kelas $\mathrm{X}$ salah satu SMK di Purbalingga jurusan akuntansi dan keuangan lembaga, otomatisasi dan tata kelola perkantoran, bisnis daring dan 
pemasaran, rekayasa perangkat lunak, serta teknik komputer dan jaringan.

Teknik sampel yang digunakan adalah teknik acak sederhana. Populasi penelitian ini berjumlah 498 siswa. Sampel penelitian ini $30 \%$ dari jumlah populasi, sehingga total sampel berjumlah 150 siswa.

Hipotesis yang dioperasionalkan adalah terdapat hubungan yang positif antara sosialisasi gender dalam keluarga dengan persepsi gender responden SMK. Data hasil penelitian dianalisis dengan tabel distribusi frekuensi untuk menggambarkan persebaran data, tabel silang untuk menentukan kecenderungan arah hubungan antarvariabel, dan korelasi tau kendall untuk menentukan nilai korelasi antarvariabel (Martono, 2010).

\section{Hasil dan pembahasan}

Salah satu media yang digunakan dalam sosialisasi gender adalah melalui agen keluarga. Keluarga merupakan kelompok primer yang terdiri orang-orang karena hubungan sedarah maupun kepemilikan hak asuh. Keluarga inti terdiri dari ayah ibu dan anak-anak. Dalam kehidupan masyarakat, keluarga merupakan unit terkecil yang peranannya sangat besar dan penting. Peranan yang sangat besar itu disebabkan keluarga mempunyai fungsi yang sangat penting bagi keberlangsungan hidup bermasyarakat. Apabila fungsi keluarga tidak berjalan dengan baik maka timbul ketidakserasian dalam hubungan antara anggota keluarga, dapat dikatakan keluarga itu mempunyai masalah (Yurnalis, 2014).

Hasil pengodingan hasil pengisian kuesioner dari 150 responden menunjukkan jenis kelamin laki-laki berjumlah 75 responden dan perempuan berjumlah 75 responden. semua responden menyatakan bahwa mereka tinggal bersama orang tua. Hal ini menunjukkan sosialisasi yang terjadi dalam keluarga terutama sosialisasi gender masih berlangsung. Sosialisasi dalam keluarga dapat diketahui melalui proses penanaman nilai dan norma kepada individu dengan hidup atau tinggal bersama keluarga.

Namun, intensitas bertemu antara anak dan orang tua menjadi salah satu faktor yang menentukan sosialisasi gender dalam keluarga. Berikut ini tabel yang menggambarkan waktu responden bertemu orang tua.

Tabel 1. Waktu responden bertemu orang tua

\begin{tabular}{clcc}
\hline No & \multicolumn{1}{c}{ Waktu } & Jumlah & $\mathbf{\%}$ \\
\hline 1. & Siang hari & 3 & 2,0 \\
\hline 2. & Pagi hari & 16 & 10,7 \\
\hline 3. & Malam hari & 71 & 47,3 \\
\hline 4. & Sore hari & 38 & 25,3 \\
\hline 5. & $\begin{array}{l}\text { Ketika libur } \\
\text { sekolah }\end{array}$ & 22 & 14,7 \\
\hline & Total & 150 & 100,0 \\
\hline
\end{tabular}

Berdasarkan tabel 1, terdapat waktu-waktu responden dan orang tua bertemu untuk melakukan interaksi. Sebagian besar responden bertemu orang tua pada malam hari, dan sedikit responden bertemu orang pada siang hari. Saat malam hari, responden dan orang tua lebih sering bertemu karena keduanya tidak melakukan kegiatan di luar rumah.

Ketika responden dan orang tua bertemu, aktivitas yang dilakukan saat bersama adalah sebagai berikut.

Tabel 2. Aktivitas responden ketika berkumpul dengan orang tua

\begin{tabular}{llcc}
\hline No & \multicolumn{1}{c}{ Aktivitas } & Jumlah & $\mathbf{\%}$ \\
\hline 1. & Mengobrol & 115 & 76 \\
\hline 2. & Menonton Tv & 67 & 44,7 \\
\hline 3. & Sibuk bermain & 18 & 12
\end{tabular}




\begin{tabular}{llcc}
\hline & gadget & & \\
\hline 4. & Makan bersama & 45 & 30 \\
\hline 5. & Jalan-jalan & 8 & 5,3 \\
\hline
\end{tabular}

Berdasarkan tabel 2, aktivitas yang sering dilakukan respoden ketika berkumpul dengan orang tua adalah mengobrol, sedangkan yang paling jarang adalah jalan-jalan. Interaksi berupa mengobrol yang dilakukan responden dan orang tua merupakan salah satu kesempatan berlangsungnya sosialisasi gender. Kegiatan mengobrol yang dilakukan responden dan orang tua secara tidak langsung dapat menjadi media sosialisasi gender. Responden menyatakan bahwa kegiatan mengobrol dengan orang tua menjadi salah satu kebiasaan yang dilakukan ketika keduanya bertemu.

Berikut tema obrolan antara responden dengan orang tua.

Tabel 3. Tema obrolan dengan orang tua

\begin{tabular}{|c|c|c|c|}
\hline No. & Aktivitas & Jumlah & $\%$ \\
\hline 1. & Masalah politik & 10 & 6,7 \\
\hline 2. & $\begin{array}{l}\text { Masalah } \\
\text { budaya }\end{array}$ & 13 & 8,7 \\
\hline 3. & Masalah hobi & 24 & 16 \\
\hline 4. & Kegiatan sehari-hari & 141 & 94 \\
\hline 5. & Masalah keluarga & 24 & 16 \\
\hline 6. & Menggosip & 8 & 5,3 \\
\hline 7. & $\begin{array}{l}\text { Curhat masalah teman } \\
\text { atau pacar }\end{array}$ & 21 & 14 \\
\hline
\end{tabular}

Tabel 3 menunjukkan bahwa responden dan orang tua lebih sering mengobrol mengenai kegiatan sehari-hari. Tema berdiskusi tersebut akan menjaga komunikasi antara responden dan orang tua dan akan membangun kedekatan hubungan antara keduanya, karena dengan mengobrol masalah sehari-hari responden dan orang tua akan saling terbuka.

Aktivitas mengobrol yang dilakukan antara responden dengan orang tua menjadi kesempatan orang tua untuk menjelaskan perilaku yang pantas atau tidak pantas dilakukan responden laki-laki dan perempuan. Akan tetapi tidak semua responden menyatakan orang tuanya menjelaskan mengenai aktivitas yang pantas atau tidak pantas dilakukan seorang laki-laki maupun perempuan. Data tersebut ditunjukkan melalui tabel 4.

Tabel 4. Orang tua menjelaskan perilaku pantas atau tidak

\begin{tabular}{clcc}
\hline No. & Aktivitas & Jumlah & $\mathbf{\%}$ \\
\hline 1. & Tidak pernah & 5 & 3,3 \\
\hline 2. & Pernah & 145 & 96,7 \\
\hline 3. & Total & 150 & 100,0 \\
\hline
\end{tabular}

Tabel 4 menunjukkan bahwa sebagian banyak responden (96,7\%) menyatakan bahwa orang tuanya pernah menjelaskan mengenai perilaku apa saja yang pantas atau tidak pantas dilakukan. Penjelasan orang tua yang diberikan kepada responden tidak sama antara orang tua satu dengan yang lain. Pengetahuan dan pemahaman orang tua mengenai gender menjadi salah satu hal utama yang perlu diperhatikan karena responden akan menerima penjelasan tersebut untuk diterapkan dalam kehidupan sehari-hari.

Penjelasan perilaku pantas atau tidak pantas dari orang tua akan menimbulkan pandangan responden mengenai beberapa perilaku menjadi tidak setara antara laki-laki dan perempuan sebagai berikut.

Tabel 5. Aktivitas yang pantas dilakukan lakilaki dan perempuan

\begin{tabular}{clcc}
\hline No. & \multicolumn{1}{c}{ Perilaku } & Jumlah & $\mathbf{\%}$ \\
\hline 1. & $\begin{array}{l}\text { Pergi sampai larut } \\
\text { malam }\end{array}$ & 0 & 0 \\
\hline 2. & Merokok & 0 & 0 \\
\hline 3. & Berhias & 12 & 8 \\
\hline 4. & Menangis & 38 & 25,3 \\
\hline
\end{tabular}




\begin{tabular}{clcc}
\hline 5. & Bermain boneka & 10 & 6,7 \\
\hline 6. & Mencuci pakaian & 122 & 81,3 \\
\hline 7. & $\begin{array}{l}\text { Mencuci } \\
\text { piring/gelas }\end{array}$ & 117 & 78 \\
\hline 8. & Menyetrika & 108 & 72 \\
\hline 9. & Memasak & 100 & 66,7 \\
\hline 10. & $\begin{array}{l}\text { Mencuci } \\
\text { motor/mobil }\end{array}$ & 33 & 22 \\
\hline 11. & Belanja & 77 & 51,3 \\
\hline 12. & $\begin{array}{l}\text { Bermain layang- } \\
\text { layang }\end{array}$ & 14 & 9,3 \\
\hline 13. & Menyapu & 113 & 75,3 \\
\hline
\end{tabular}

Tabel 5 menunjukkan bahwa sebagian besar responden menyatakan sebagian besar aktivitas yang disebutkan dalam kuesioner pantas dilakukan laki-laki maupun perempuan. Namun, ada beberapa aktivitas yang menurut responden tidak pantas dilakukan laki-laki atau perempuan, yaitu: pergi sampai larut malam dan merokok. Sebagian besar responden menyatakan bahwa kedua aktivitas tersebut tidak pantas dilakukan seorang perempuan.

Keluarga memiliki aturan-aturan yang harus ditaati anggota keluarga. Namun, aturan-aturan tersebut tidak selalu sama antara keluarga satu dengan yang lain. Kemudian, responden akan menerapkan aturan-aturan yang sudah ia kenal sejak bersama orang tua untuk diterapkan di kehidupan selanjutnya. Aturan-aturan tersebut adalah sebagai berikut.

Tabel 6. Aturan dalam keluarga

\begin{tabular}{clcc}
\hline No. & \multicolumn{1}{c}{ Perilaku } & Jumlah & \% \\
\hline 1. & $\begin{array}{l}\text { Aturan berupa sikap } \\
\text { dan perilaku }\end{array}$ & 51 & 34 \\
\hline 2. & $\begin{array}{l}\text { Aturan pembatasan jam } \\
\text { malam }\end{array}$ & 26 & 17,3 \\
\hline 3. & $\begin{array}{l}\text { Aturan yang berkaitan } \\
\text { dengan } \\
\text { keagamaan }\end{array}$ & 8 & 5,3 \\
\hline
\end{tabular}

Aturan dalam keluarga sesuai data pada tabel 6, meliputi aturan sikap dan perilaku, aturan pembatasan jam malam, dan aturan yang berkaitan dengan aktivitas keagamaan. Aturan yang berkaitan dengan aktivitas keagamaan dirasakan sama antara responden laki-laki dan perempuan, bahwa keduanya harus tertib untuk menjalankan ibadah. Aturan sikap dan perilaku diterapkan berbeda pada responden lakilaki dan perempuan. Aturan sikap dan perilaku pada responden laki-laki diperbolehkan untuk tertawa dengan keras, berbeda dengan responden perempuan harus menjaga sikap untuk terlihat anggun. Aturan pembatasan jam malam pada responden laki-laki diperbolehkan hingga malam, sedangkan responden perempuan tidak boleh sampai malam karena dianggap tidak patut apabila anak perempuan pulang malam.

Aturan keluarga tersebut diterapkan berbeda pada responden laki-laki dan perempuan. Menurut responden yang memiliki saudara berbeda jenis kelamin, mereka menyatakan bahwa orang tua memperlakukan responden dan saudaranya secara berbeda. Perbedaan tersebut nampak pada tabel 7 .

Tabel 7. Perlakuan berbeda antarsaudara responden beda jenis kelamin

\begin{tabular}{clcc}
\hline No & \multicolumn{1}{c}{ Aktivitas } & Jumlah & \% \\
\hline 1. & $\begin{array}{l}\text { Tidak memiliki } \\
\text { saudara beda jenis } \\
\text { kelamin }\end{array}$ & 20 & 13,3 \\
\hline 2. & $\begin{array}{l}\text { Diperlakukan } \\
\text { berbeda dengan } \\
\text { saudara beda jeni } \\
\text { kelamin }\end{array}$ & 36 & 24 \\
\hline 3 & $\begin{array}{l}\text { Tidak } \\
\text { diperlakukan } \\
\text { berbeda dengan } \\
\text { saudara beda jenis } \\
\text { kelamin }\end{array}$ & 94 & 62,7 \\
\hline & Jumlah & 150 & 100 \\
\hline
\end{tabular}


Tabel 7 menunjukkan 20 responden tidak memiliki saudara, dan terdapat 36 responden mengalami perbedaan perlakuan antarsaudara beda jenis kelamin. Hal tersebut di antaranya adalah perlakuan berupa perbedaan beban pekerjaan rumah karena memandang fisik responden lakilaki dan perempuan, seperti tanggung jawab responden perempuan memasak dan responden laki-laki mengangkat galon. Beberapa responden perempuan menyatakan mereka lebih dimanja. Hal ini menunjukan beberapa orang tua memberikan perlakuan berupa kasih sayang atau perhatian yang berbeda antara anak laki-laki dan perempuan.

Perbedaan tugas pekerjaan rumah yang diberikan orang tua kepada responden laki-laki dan perempuan juga berbeda. data ini disajikan pada tabel 8 berikut.

Tabel 8. Tugas pekerjaan rumah yang diberikan pada responden

\begin{tabular}{|c|c|c|c|c|c|}
\hline No. & Kegiatan & Perempuan & $\%$ & $\begin{array}{c}\text { Laki- } \\
\text { laki }\end{array}$ & $\%$ \\
\hline 1. & $\begin{array}{l}\text { Mencuci } \\
\text { piring }\end{array}$ & 52 & 53,6 & 45 & 46,4 \\
\hline 2. & $\begin{array}{l}\text { Menyapu } \\
\text { lantai }\end{array}$ & 59 & 54,1 & 50 & 45,9 \\
\hline 3. & $\begin{array}{l}\text { Menyapu } \\
\text { halaman }\end{array}$ & 35 & 55,6 & 28 & 44,4 \\
\hline 4. & $\begin{array}{l}\text { Mencuci } \\
\text { pakaian }\end{array}$ & 42 & 72,4 & 16 & 27,6 \\
\hline 5. & Mengepel & 38 & 62,3 & 23 & 37,7 \\
\hline 6. & Belanja & 20 & 55,6 & 16 & 44,4 \\
\hline 7. & Memasak & 43 & 69,4 & 19 & 30,6 \\
\hline 8. & Menyetrika & 42 & 75 & 12 & 25 \\
\hline 9. & $\begin{array}{l}\text { Mengisi bak } \\
\text { mandi }\end{array}$ & 22 & 45,8 & 26 & 54,2 \\
\hline 10. & $\begin{array}{l}\text { Mengganti } \\
\text { lampu }\end{array}$ & 7 & 24,1 & 22 & 75,9 \\
\hline 11. & Membeli gas & 20 & 38,5 & 32 & 61,5 \\
\hline 12. & $\begin{array}{l}\text { Memasang } \\
\text { selang gas }\end{array}$ & 8 & 42,1 & 11 & 57,9 \\
\hline 13. & $\begin{array}{l}\text { Membeli air } \\
\text { galon }\end{array}$ & 9 & 39,1 & 14 & 60,9 \\
\hline
\end{tabular}

Tabel 8 menunjukkan ada perbedaan tugas yang diberikan orang tua kepada responden laki-laki dan perempuan. Menurut data tabel 8, responden perempuan cenderung lebih sering ditugaskan pada pekerjaan rumah yang dikonstruk masyarakat sebagai kegiatan yang dilakukan ibu atau istri seperti: mencuci piring, menyapu lantai, menyapu halaman, mencuci pakaian, mengepel, belanja, memasak, dan menyetrika. Responden laki-laki lebih sering ditugaskan pada pekerjaan yang dikonstruk masyarakat sebagai kegiatan yang dilakukan ayah atau suami seperti: mengisi bak mandi, mengganti lampu, membeli gas, memasang selang gas, membeli air galon.

Sosialisasi gender dalam keluarga juga dapat dilakukan melalui pembagian peran atau pekerjaan ayah dan ibu di rumah. Pembagian kerja ini dapat menimbulkan persepsi mengenai peran ayah sebagai laki-laki dan ibu sebagai perempuan. Berikut tabel yang menunjukkan pembagian kerja ayah dan ibu di rumah.

Tabel 9. Pekerjaan rumah yang dilakukan orang tua

\begin{tabular}{llcccc}
\hline No. & Kegiatan & Ibu & $\mathbf{\%}$ & Ayah & $\mathbf{\%}$ \\
\hline 1. & $\begin{array}{l}\text { Mencuci } \\
\text { piring }\end{array}$ & 138 & 92 & 12 & 8 \\
\hline 2. & $\begin{array}{l}\text { Menyapu } \\
\text { lantai }\end{array}$ & 131 & 87,3 & 19 & 12,7 \\
\hline 3. & $\begin{array}{l}\text { Menyapu } \\
\text { halaman }\end{array}$ & 103 & 68,7 & 47 & $\begin{array}{c}31, \\
3\end{array}$ \\
\hline 4. & $\begin{array}{l}\text { Mencuci } \\
\text { pakaian }\end{array}$ & 135 & 90,0 & 15 & $\begin{array}{c}10, \\
0\end{array}$ \\
\hline 5. & Mengepel & 127 & 84,7 & 23 & $\begin{array}{c}15, \\
3\end{array}$ \\
\hline 6. & Belanja & 141 & 94,0 & 9 & 6,0 \\
\hline 7. & Memasak & 143 & 95,3 & 7 & 4,7 \\
\hline 8. & Menyetrika & 142 & 94,7 & 8 & 5,3 \\
\hline 9. & $\begin{array}{l}\text { Mengisi bak } \\
\text { mandi }\end{array}$ & 64 & 42,7 & 86 & 57, \\
\hline 10. & Mengganti & 15 & 10,0 & 135 & 90, \\
\hline & & & & & \\
\hline
\end{tabular}




\begin{tabular}{|c|c|c|c|c|c|}
\hline & lampu & & & & 0 \\
\hline 11. & Membeli gas & 78 & 52,0 & 72 & $\begin{array}{c}48, \\
0\end{array}$ \\
\hline 12 . & $\begin{array}{l}\text { Memasang } \\
\text { selang gas }\end{array}$ & 59 & 39,3 & 91 & $\begin{array}{c}60, \\
7\end{array}$ \\
\hline 13. & $\begin{array}{l}\text { Membeli air } \\
\text { galon }\end{array}$ & 32 & 21,3 & 118 & $\begin{array}{c}78, \\
7\end{array}$ \\
\hline
\end{tabular}

Berdasarkan tabel 9 ibu lebih sering berperan untuk melakukan kegiatan seperti: mencuci piring, menyapu lantai, menyapu halaman, mencuci pakaian, mengepel, belanja, memasak, dan menyetrika. Kegiatan yang sering dibebankan pada ibu merupakan hasil konstruksi dari masyarakat bahwa ibu patut untuk melakukan pekerjaan yang berkaitan dengan bersih-bersih dan kegiatan di dapur. Kemudian, ayah lebih sering melakukan pekerjaan seperti mengisi bak mandi, mengganti lampu, memasang selang gas, dan membeli air galon. Kegiatan yang lebih sering diperankan ayah tersebut dikonstruk sebagai kegiatan yang patut dilakukan oleh ayah atau suami karena dipandang membutuhkan tenaga yang lebih kuat dibandingkan bersih-bersih dan kegiatan di dapur yang dilakukan ibu atau istri dalam keluarga.

Tabel 8 berkaitan dengan tabel 9 , karena anak akan belajar dengan melihat aktivitas yang dilakukan orang tuanya. Data pada tabel 9 menunjukkan bahwa ibu melakukan kegiatan mencuci piring, menyapu lantai, menyapu halaman, mencuci pakaian, mengepel, belanja, memasak, dan menyetrika tidak jauh berbeda dengan tugas pekerjaan rumah yang diberikan pada responden perempuan. Begitupun peran ayah yang melakukan kegiatan mengisi bak mandi, mengganti lampu, memasang selang gas, dan membeli air galon akan dilakukan responden lakilaki sebagai tugas yang diberikan untuk melakukan pekerjaan rumah dalam keluarga.

Data berikutnya menunjukkan persepsi gender responden. Seluruh responden pernah mendengar istilah gender dari beberapa sumber sebagai berikut.

Tabel 10. Sumber mendengar istilah gender

\begin{tabular}{clcc}
\hline No. & \multicolumn{1}{c}{ Sumber } & Jumlah & \% \\
\hline 1. & $\begin{array}{l}\text { Media sosial/ } \\
\text { internet }\end{array}$ & 35 & 23,3 \\
\hline 2. & Buku/ majalah & 9 & 6,0 \\
\hline 3. & Guru & 100 & 66,7 \\
\hline 4. & TV/ radio/ koran & 2 & 1,3 \\
\hline 5. & Teman bermain & 1 & 0,7 \\
\hline 6. & $\begin{array}{l}\text { Orang tua/ anggota } \\
\text { keluarga }\end{array}$ & 3 & 2,0 \\
\hline & Total & 150 & 100,0 \\
\hline
\end{tabular}

Berdasarkan tabel 10 responden tidak mendengar langsung istilah gender dari orang tua atau anggota keluarga, namun responden lebih sering mendengar istilah gender dari guru. Hal tersebut mengindikasikan bahwa responden telah mengetahui istilah gender dari gurunya meskipun sebenarnya responden telah mengalami sosialisasi gender dalam keluarga. Responden yang telah mendengar istilah gender dari guru dan mengalami sosialisasi gender dalam keluarga kemudian akan memiliki pengetahuan mengenai definisi gender sebagai berikut.

Tabel 11. Pengetahuan tentang gender

\begin{tabular}{|c|c|c|c|}
\hline No. & Pengetahuan & Jumlah & $\%$ \\
\hline \multirow[t]{2}{*}{1.} & Pembedaan jenis & & \\
\hline & $\begin{array}{l}\text { kelamin laki-laki } \\
\text { dan perempuan }\end{array}$ & 106 & 70,7 \\
\hline 2. & $\begin{array}{lr}\text { Pembedaan } & \text { peran } \\
\text { laki-laki } & \text { dan } \\
\text { perempuan } & \end{array}$ & 42 & 28,0 \\
\hline 3. & $\begin{array}{lr}\text { Pembedaan } & \text { peran } \\
\text { laki-laki } & \text { dan }\end{array}$ & 2 & 1,3 \\
\hline
\end{tabular}




\begin{tabular}{lll}
\hline $\begin{array}{l}\text { perempuan } \\
\text { dibentuk } \\
\text { masyarakat }\end{array}$ & & \\
\hline Total & 150 & 100,0 \\
\hline
\end{tabular}

Berdasarkan tabel 11 hanya terdapat 2 responden yang mengetahui gender secara tepat bahwa gender merupakan pembedaan peran laki-laki dan perempuan yang dibentuk oleh masyarakat, sedangkan 106 responden hanya mengetahui gender sebagai pembedaan jenis kelamin laki-laki dan perempuan. Pengetahuan responden mengenai gender yang minim tersebut akan memengaruhi pemahaman responden mengenai gender. Berikut ini adalah pemahaman responden mengenai hal-hal yang berkaitan dengan gender menurut.

Tabel 12. Pemahaman tentang gender

\begin{tabular}{clcc}
\hline No. & \multicolumn{1}{c}{ Pemahaman } & Jumlah & \% \\
\hline 1. & $\begin{array}{l}\text { Istilah gender adalah } \\
\text { sama dengan jenis } \\
\text { kelamin }\end{array}$ & 69 & 46,0 \\
\hline 2. & $\begin{array}{l}\text { Pembedaan kerja laki- } \\
\text { laki dan perempuan } \\
\text { didasarkan pada faktor } \\
\text { biologis }\end{array}$ & 78 & 52,0 \\
\hline 3. & $\begin{array}{l}\text { Di dalam masyarakat } \\
\text { laki-laki harus lebih kuat } \\
\text { daripada perempuan }\end{array}$ & 60 & 40,0 \\
\hline 4. & $\begin{array}{l}\text { Laki-laki harus menjadi } \\
\text { pemimpin }\end{array}$ & 77 & 51,3 \\
\hline 5. & $\begin{array}{l}\text { Mencari nafkah adalah } \\
\text { tanggung jawab laki-laki }\end{array}$ & 93 & 62,0 \\
\hline 6. & $\begin{array}{l}\text { Mengasuh anak adalah } \\
\text { tugas perempuan }\end{array}$ & 84 & 56,0 \\
\hline 7. & $\begin{array}{l}\text { Memasak adalah tugas } \\
\text { perempuan }\end{array}$ & 87 & 58,0 \\
\hline 8. & Laki-laki harus bekerja & 108 & 72,0 \\
\hline 9. & $\begin{array}{l}\text { Perempuan harus terlihat } \\
\text { feminim dan lemah } \\
\text { lembut }\end{array}$ & 87 & 58,0 \\
\hline
\end{tabular}

Tabel 12 menunjukkan bahwa responden memiliki pemahaman bahwa laki-laki yang disosialisasikan sebagai sosok ayah dalam keluarga harus menjadi seorang pemimpin $(51 \%)$ yang memiliki tanggung jawab untuk mencari nafkah $(62 \%)$ dan memiliki kewajiban untuk bekerja (72\%). Kemudian pemahaman responden mengenai perempuan yang disosialisasikan sebagai sosok ibu dalam keluarga bahwa perempuan memiliki tugas mengasuh anak (56\%) dan memasak (58\%). Responden juga memahami bahwa perempuan harus terlihat feminim dan lemah lembut (58\%), berbeda dengan lakilaki yang harus lebih kuat daripada perempuan (40\%). Pemahaman responden tersebut menjadi salah satu indikasi bahwa proses sosialisasi gender yang lakukan melalui agen sosialisasi keluarga menghasilkan persepsi gender responden adalah sama dengan jenis kelamin serta terdapat perbedaan peran antara laki-laki dan perempuan yang tidak adil gender.

Persepsi gender responden tersebut dibentuk melalui sosialisasi gender dalam keluarga. Persepsi gender responden menyatakan bahwa laki-laki adalah sosok yang maskulin dan perempuan adalah sosok yang feminin berdasarkan pada apa yang digambarkan sebagai perempuan oleh sosok ibu dan laki-laki oleh sosok ayah dalam keluarga.

Hasil penelitian ini menunjukkan hubungan antara sosialisasi gender dalam keluarga dengan persepsi gender sebagai berikut.

Tabel 13. Hubungan sosialisasi gender dalam keluarga dengan persepsi gender responden

\begin{tabular}{|c|c|c|c|c|}
\hline \multirow[b]{2}{*}{$\begin{array}{c}\text { Sosialisasi } \\
\text { Gender }\end{array}$} & \multicolumn{3}{|c|}{ Persepsi Gender } & \multirow[b]{2}{*}{$\begin{array}{c}\text { Total } \\
(\%)\end{array}$} \\
\hline & $\begin{array}{c}\text { Rendah } \\
(\%)\end{array}$ & $\begin{array}{c}\text { Sedang } \\
(\%)\end{array}$ & $\begin{array}{c}\text { Tinggi } \\
(\%)\end{array}$ & \\
\hline $\begin{array}{c}\text { Rendah } \\
(\%)\end{array}$ & $\begin{array}{c}4 \\
(44,4)\end{array}$ & $\begin{array}{c}5 \\
(56,6)\end{array}$ & $\begin{array}{c}0 \\
(0,0)\end{array}$ & $\begin{array}{c}9 \\
(100)\end{array}$ \\
\hline $\begin{array}{c}\text { Sedang } \\
(\%)\end{array}$ & $\begin{array}{c}30 \\
(36,6)\end{array}$ & $\begin{array}{c}47 \\
(57,3)\end{array}$ & $\begin{array}{c}5 \\
(6,1)\end{array}$ & $\begin{array}{c}82 \\
(100)\end{array}$ \\
\hline
\end{tabular}




\begin{tabular}{ccccc}
\hline Tinggi & 14 & 41 & 4 & 59 \\
$\mathbf{( \% )}$ & $(23,7)$ & $(69,5)$ & $(6,8)$ & $(100)$ \\
\hline
\end{tabular}

Tabel 13 menunjukkan bahwa terdapat hubungan yang positif antara sosialisasi gender dalam keluarga dengan persepsi gender responden. Berdasarkan hasil uji tau kendall hubungan antara sosialisasi gender dalam keluarga dengan persepsi gender responden terdapat hubungan positif sebesar 0,14 dengan nilai signifikansi sebesar 0,07 .

Aktivitas bersama yang dilakukan responden dan orang tua menjadi kesempatan berlangsungnya sosialisasi gender dalam keluarga. Proses sosialisasi gender yang dilakukan oleh orang tua terhadap responden berbeda antara responden satu dengan yang lainnya. Hal tersebut menjadi salah satu indikasi terbentuknya persepsi responden mengenai gender.

Berdasarkan hasil penelitian sosialisasi gender dalam keluarga bagus, namun sosialisasi gender yang berlangsung mengandung bias gender. Bias gender dalam pembagian kerja ini ditunjukkan pada tabel 8 dan 9 .

Nilai korelasi yang rendah menunjukkan bahwa masih ada variabel lain yang menentukan persepsi gender responden, di antaranya sosialisasi di sekolah, sosialisasi dengan teman sebaya, lingkungan masyarakat berdasarkan budaya termasuk media massa.

Lingkungan sosial merupakan tempat perkembangan emotional question (EQ) yang lebih dikenal dengan perkembangan emosi anak. Menurut Soekanto (Mahendradhani, 2020) lingkungan sosial terdiri atas orang-orang baik individu maupun kelompok yang berada di sekitar. Berdasarkan pernyataan tersebut, lingkungan sosial merupakan wadah interaksi antarindividu satu dengan lainnya baik yang memiliki jenis kelamin perempuan maupun laki-laki. Lingkungan sosial sama pentingnya dengan lingkungan keluarga, orang tua memberikan sosialisasi gender paling awal kepada anak dalam keluarga, namun setelah sosialisasi gender yang dilakukan dalam keluaga tidak lama kemudian lingkungan sosial akan ikut serta dalam proses sosialisasi gender dalam merespon dan meniru perilaku maskulin dan feminin (Suci, 2016) Sosialisasi gender di sekolah berlangsung melalui guru, berdasarkan data pada tabel 10 responden lebih sering mendengar istilah gender dari guru. Guru sebagai panutan di lingkungan sekolah mengindikasikan bahwa berlangsungnya sosialisasi gender di sekolah berhubungan dengan persepsi gender responden.

Teman sebaya adalah agen sosialisasi yang berpengaruh terhadap perilaku individu dan menjadi sumber afeksi serta tempat untuk bereksperimen dalam membentuk hubungan mendalam dengan orang lain selain keluarga, sehingga remaja lebih senang menghabiskan waktu bersama dengan teman sebaya (Putri \& Dewi, 2019; Kurniawan \& Sudrajat, 2018). Sikap orang tua dalam keluarga dan teman sebaya bekerja saling melengkapi dalam proses sosialisasi gender. Pola sosialisasi gender yang terjadi di lingkungan sosial teman sebaya berhubungan dengan tindakan dan persepsi gender responden (Boediarsih, Shaluhiyah, \& Syamsulhuda, 2016). Responden laki-laki dan perempuan akan melakukan apa yang mereka lihat ketika berinteraksi dengan teman sebaya, seperti kelompok teman sebaya laki-laki yang bermain bola berbeda dengan kelompok teman sebaya perempuan yang bermain 
masak-masakan. Responden akan memiliki persepsi gender bahwa laki-laki patut untuk bermain bola sedangkan perempuan patut bermain masak-masakan.

Masyarakat sebagai kelompok sosial memiliki peran sebagai agen sosialisasi gender. Secara implementatif, masyarakat sudah melakukan sosialisasi gender, namun masyarakat belum memahami arti atau makna kesetaraan gender (Qomariah, 2019). Sosialisasi gender yang dilakukan oleh masyarakat dipengaruhi oleh budaya lingkungan setempat. Sikap dan perilaku individu dipengaruhi budaya masyarakat sekitar. Menurut Skinner (Suci, 2016) sikap dan perilaku individu sudah lama terikat pada budaya. Pengaruh budaya di masyarakat dalam sosialisasi gender dimulai dengan peran yang mengategorisasikan dan mengeneralisasi seorang individu baik laki-laki maupun perempuan.

Perilaku individu berdasarkan budaya turun-temurun akan membentuk konstruk yang dipercayai sebagai kodrat atau tidak dapat diubah, seperti halnya budaya masyarakat yang memiliki persepsi gender bahwa peran laki-laki dan perempuan tidak sama karena dipandang berdasarkan perbedaan biologis. Sebelum responden memiliki hubungan dengan lingkungan sosial teman sebaya, budaya yang telah dibentuk masyarakat sudah dahulu ditanamkan di lingkungan keluarga. Ketika responden laki-laki bermain bola dan perempuan bermain masak-masakan, perilaku atau kegiatan tersebut sudah menjadi konstruk di masyarakat, bahwa laki-laki berperan untuk kegiatan yang dianggap membutuhkan fisik yang kuat sedangkan perempuan berperan untuk kegiatan di rumah atau di dapur. Kegiatan yang membedakan laki-laki dan perempuan tersebut semakin kuat untuk membentuk persepsi gender responden.

Sosialisasi gender berhubungan lingkungan masyarakat termasuk media massa. Media sosial termasuk media massa yang sedang marak digunakan pun menjadi salah satu kesempatan berlangsungnya sosialisasi gender. Melalui berbagai informasi yang dilihat oleh responden mengenai gender akan membentuk persepsi gender responden (Ramadhan \& Giyarsih, 2017)

\section{Simpulan}

Berdasarkan penelitian terdapat hubungan positif antara sosialisasi gender dalam keluarga dengan persepsi gender responden. Nilai korelasi kedua variabel tersebut sebedar 0,014 dengan signifikansi 0,07 . Responden mengalami proses sosialisasi gender di dalam keluarga melalui berbagai kesempatan aktivitas yang dilakukan di rumah. Sosialisasi gender yang dialami responden membentuk persepsi mengenai gender, peran laki-laki yang digambarkan sosok ayah dan perempuan oleh sosok ibu. Selain sosialisasi gender dalam keluarga, terdapat faktor lain yang berhubungan dengan persepsi responden mengenai gender. Faktor-faktor tersebut adalah sosialisasi di sekolah, sosialisasi dengan teman sebaya, lingkungan masyarakat berdasarkan budaya termasuk media massa.

\section{Referensi}

Berliana. (2014). Analisis Peran Pola Asuhan dan Proses Sosialisasi Olahraga Beladiri Ditinjau dari Perspektif Kesetaraan Gender. Jurnal Cakrawala Pendidikan, 33(3), 454-462. 
Boediarsih, Shaluhiyah, Z., \&

Syamsulhuda. (2016). Persepsi

Remaja tentang Peran Gender dan

Gender Seksualitas di Kota

Semarang. Jurnal Promosi

Kesehatan Indonesia, 11(1), 28-38.

Creswell, J. W., \& Creswell, J. D. (2018).

Research Design: Qualitative,

Quantitative, and Mixed Methods

Approaches. Los Angeles: SAGE.

González, J. G., Forcén, P., \& Jim, M.

(2019). Men and Women Differ in

Their Perception of Gender Bias in

Research Institutions.

Journals.plos.org, 14(12), 1-11.

Jacobson, D. (2015). Elementary Studens

Perceptions of Gender Equity in

Mathematics. Lynchburg, Virginia:

Liberty University.

Jayanti, F., \& Arista, N. T. (2018).

Persepsi Mahasiswa Terhadap

Pelayanan Perpustakaan

Universitas Trunojoyo Madura.

Jurnal Kompetensi, 12(2), 205-223.

Küçükşen, K. (2016). Perception of

Gender Equality in New Media.

International Journal of Human

Sciences, 13(1), 1-9.

Kurniawan, Y., \& Sudrajat, A. (2018).

Peran teman sebaya dalam

pembentukan karakter

siswamadrasah tsanawiyah. Jurnal

Ilmu-Ilmu Sosial, 15(2), 149-163.

Kurniawati, D. (2014). Konflik Gender di

Ruang Keluarga dalam Cerpen

Kalimantan Timur. Jurnal LOA,

9(1), 49-58.

Kusumo, B., Andriani, R., \& Charina, A.

(2013). Analisis Gender dalam

Kehidupan Keluarga Nelayan di

Kecamatan Pangan daran

Kabupaten Ciamis. Jurnal Social
Economic of Agrikultur, 2(1), 42-

53.

Mahendradhani, G. A. (2020). Pendidikan

Seks Bagi Anak Sejak Dini

Perspektif Gender Sebagai Bentuk

Kemandirian Dalam Lingkungan

Sosial. Sphatika Jurnal Teologi,

11(1), 97-104.

Martono, N. (2010). Statistik Sosial Teori

dan Aplikasi Program SPSS.

Yogyakarta: Penerbit Gava Media.

Miskahuddi. (2014). Pengaruh Sosialisasi

Gender Terhadap Pembentukan

Pola Pikir Perempuan Aceh (Studi

Kasus di Banda Aceh dan Banda

Besar). Ar-Raniry: International

Journal of Islamic Studies, 1(2),

297-316.

Nuraida, \& Hassan, M. Z. (2017). Pola

Komunikasi Gender Dalam

Keluarga. Jurnal Wardah, 18(2), 181-200.

Pattiruhu, I. C., Rompas, S., \& Simak, V. (2019). Fungsi Afektif Keluarga dan Fungsi Sosialisasi Keluarga dengan Perilaku Seksual Remaja. Jurnal Keperawatan, 7(2), 1-9.

Prabowo, D. P. (2019). Penerapan Asas

Kesetaraan dan Keadilan Gender dalam Undang-Undang Nomor 18 Tahun 2017 tentang Perlindungan

Pekerja Migran Indonesia

Perspektif Maslahah Mursalah

(Studi di Pos Pelayanan

Penempatan dan Perlindungan

Tenaga Kerja Indonesia Malang). Journal of Family Studies, 3(4), 110.

Probosiwi, R. (2015). Perempuan dan Perannya dalam Pembangunan Kesejahteraan Sosial. Jurnal Kajian Ilmu Administrasi Negara, 3(1), 41-56. 
Puspitawati, H., \& Fahmi, S. A. (2008). Analisis Pembagian Peran Gender pada Keluarga Petani. Jurnal Ilmu Keluarga dan Konsumen, 1(2), 110.

Putri, D. R., \& Dewi, N. (2019).

Kohesivitas Kelompok Teman

Sebaya, Gender, dan Kesehatan

Mental Siswa SMP Negeri 2

Surakarta. Jurnal Ilmu

Keperawatan Indonesia, 12(2), 171-178.

Qomariah, D. N. (2019). Persepsi

Masyarakat Mengenai Kesetaraan

Gender dalam Keluarga. Jurnal

Cendekiawan Ilmiah PLS, 4(2), 52-

58.

Rahmadhani, G. A., \& Virianita, R. (2020).

Pengaruh Stereotipe Gender dan

Konflik Peran Gender Laki-laki

Terhadap Motivasi Kerja Pemuda

Desa Putus Sekolah di Desa

Sukawening Kecamatan Dramaga,

Kabupaten Bogor, Jawa Barat.

Jurnal Sains Komunikasi dan

Pengembangan Masyarakat, 4(2),

217-324.

Ramadhan, H. W., \& Giyarsih, S. R.

(2017). Hubungan Media Sosial

Dengan Persepsi Remaja Tentang

Kesehatan Reproduksi Menurut

Wilayah Perkotaan dan Pedesaan di

Yogyakarta. Jurnal Bumi

Indonesia, 6(3), 1-13.

Ratri, S. R. (2019). Standar Ganda Gender

dalam Keluarga (Studi Kasus

Mahasiswa UIN Syarif

Hidayatullah Jakarta). Jakarta:

Fisip UIN.

Rustin. (2017). Implementasi Kesetaraan

dan Keadilan Gender dalam

Keluarga. Jurnal Musawa, 9(2),

283-308.
Suci, F. N. (2016). Hubungan Sosialisasi

Gender Orang Tua Dengan

Identitas Gender Remaja.

Universitas Islam Negeri Maulana

Malik Ibrahim: Undergraduate thesis.

Sumiarti. (2017). Relasi Gender Perspektif Perempuan Pedagang di Pasar Rawalo Banyumas. Jurnal Studi Islam Gender dan Anak, 12(2), 367-386.

Sumiarti, \& Munfarida, E. (2015). Sosialisasi Budaya Adil Gender oleh Organisasi Gender. Jurnal Studi Islam Gender dan Anak, 10(2), 196-209.

Susanti, E., Sabti, A., \& Farhani, N. (2016). Relasi Gender Pada Rumah Tangga Petani Padi Sawah di Kecamatan Mila Kabupaten Pidie. Jurnal Bisnis Tani, 2(1), 55-66.

Syarif, J. (2017). Sosialisasi Nilai-Nilai Kultural dalam Keluarga Studi Perbandingan Sosial Budaya Bangsa-Bangsa. Jurnal Kajian Kebudayaan, 7(1).

Warmiyati, M. T., Wijayanti, S. H., \& Darmoyo, S. (2018). Pemahaman Tentang Sosialisasi Gender Pada Siswa SMA di Jakarta. Jurnal Muara Ilmu Sosial, Humaniora, dan Seni, 2(1), 411-419.

Yurnalis. (2014). Sosialisasi Bimbingan Konseling Keluarga dalam Aktivitas Pengajian Islam di Desa Koto Tinggi Kecamatan Rambah Kabupaten Rokan Hulu. Menara, 13(2), 274-289. 